This is a preprint of a manuscript under review at the journal Geochimica et Cosmochimica Acta. Subsequent versions of this manuscript may have slightly different content. 


\title{
A global Bayesian temperature calibration for lacustrine brGDGTs
}

\author{
Pablo Martínez-Sosa ${ }^{\mathrm{a}}$, Jessica E. Tierney ${ }^{\mathrm{a}}$, Ioana C. Stefanescu ${ }^{\mathrm{b}}$, Emily \\ Dearing Crampton-Flood ${ }^{\mathrm{d}}$, Bryan N. Shuman ${ }^{\mathrm{b}}$, Cody Routson ${ }^{\mathrm{c}}$ \\ ${ }^{a}$ Department of Geosciences, The University of Arizona, 1040 E 4th St, Tucson, Arizona \\ 85721, USA \\ ${ }^{b}$ Department of Geology and Geophysics, University of Wyoming, Laramie, WY, USA \\ ${ }^{c}$ School of Earth Sciences and Environmental Sustainability, Northern Arizona University, \\ Arizona, USA \\ ${ }^{d}$ School of Earth and Environmental Sciences, The University of Manchester, Manchester, \\ $U K$
}

\begin{abstract}
Despite widespread use of branched glycerol dialkyl glycerol tetraethers (brGDGTs) for paleo-temperature reconstruction, no global calibration for their application in lakes has been generated since improved analytical methods have allowed for the separation of the structural isomers. This is a substantial obstacle for the application of this tool as soil calibrations underestimate temperature values when applied to lake sediments. Here, we present a comprehensive dataset ( $N=261$ ) of lacustrine brGDGT distributions spanning a wide range of geographical locations, environmental temperatures, and lakewater $\mathrm{pH}$ values. Empirical Orthogonal Function (EOF) analysis on the fractional abundance of brGDGTS indicates that temperature exerts a strong control (explaining $86 \%$ of the variance) on the lipid distribution. However, the influence of water chemistry is less clear, as $\mathrm{pH}$ and conductivity have a weak influence on brGDGT distributions. We use our dataset to generate a new Bayesian temperature calibration, which has an $R^{2}=0.85$ and $\mathrm{RMSE}=2.8^{\circ} \mathrm{C}$. Application of this new calibration to a previously published lake core record demonstrates that it generates values comparable with instrumental observations. Our new calibration facilitates the use of lacustrine brGDGTs to reconstruct continental tempera-
\end{abstract}

Email address: pmartoza@email.arizona.edu (Pablo Martínez-Sosa)

Preprint submitted to Geochimica et Cosmochimica Acta 
tures, a vital piece of information for understanding past climates.

Keywords: brGDGTs, lakes, Bayesian statistics, calibration

\section{Introduction}

Branched glycerol dialkyl glycerol tetraethers (brGDGTs) are family of membranespanning lipids consisting of two alkyl chains ether-bonded to glycerol molecules on both ends. Each of the 15 different structures varies in the number $(4-6)$

5 and position (5' or $6^{\prime}$ ) of methyl groups as well as number of cyclopentane moieties $(0-2)$ (De Jonge et al., 2013; Weijers et al., 2006). Their structure with alkyl chains and, most importantly, the stereochemistry of the glycerol group strongly point to a bacterial source (Weijers et al., 2006) for these molecules. Based on their abundance in peatlands, where brGDGTs were first described (Sinninghe Damsté et al., 2000), and the fact that this phylum is very diverse and poorly understood, Acidobacteria has been suggested as a brGDGT producer (Weijers et al. 2009). Later work showed the presence of small amounts of brGDGT Ia in two bacteria from the subgroup 1 of the Acidobacteria phylum (Sinninghe Damsté et al., 2018, 2011). Nevertheless, to this day only the build-

15 ing blocks for brGDGTs have been found in other members of the phylum, and none of the other brGDGTs have been found in any organism. More recent work has suggested that the production of brGDGTs could be linked to changes in microbial community, rather than specific organisms adapting their membranes (De Jonge et al., 2019; Weber et al., 2018).

While early literature described brGDGTs as biomarkers associated with peats and soils (Weijers et al. 2007 ; Sinninghe Damsté et al., 2000), later analyses have shown that these lipids can also be produced in aquatic environments such as lakes (Russell et al., 2018; Weber et al., 2015, Tierney et al., 2010 Tierney \& Russell, 2009), rivers (De Jonge et al., 2014b; Zell et al., 2013), and coastal areas (Xiao et al., 2016: Zhou et al., 2014, Peterse et al., 2009). Discovery of a lacustrine-specific $5 / 6$ methyl isomer provides further evidence of in situ production of brGDGTs in lakes (Weber et al., 2015), and also raises the 
possibility that the organisms involved in the production of these molecules in lakes vs. soils might be different.

The relative abundance of brGDGTs has been shown to change in response to both pH and temperature (Martínez-Sosa et al., 2020, Dang et al., 2018. De Jonge et al., 2014b; Tierney et al., 2010; Weijers et al., 2007). Weijers et al. (2007) proposed the use of two indices - the cyclisation index of branched tetraethers $(C B T)$ and methylation index of branched tetraethers $(M B T)$ - to reflect this response. Later analytical advances using High Performance Liquid Chromatography-Mass Spectrometry (HPLC-MS) (Hopmans et al., 2016. De Jonge et al., 2014a) improved these indices by separating the $5^{\prime}$ and $6^{\prime}$ isomers. $M B T_{5 M e}^{\prime}$, a new version of $M B T$, was generated excluding the $6^{\prime}$ isomers, and $C B T$ was updated to $C B T^{\prime}$ by including both $5^{\prime}$ and $6^{\prime}$ isomers (De Jonge 40 et al. 2014a).

Other environmental factors may also impact brGDGT distribution, such as soil moisture (Dang et al. 2016b), redox state (Weber et al., 2018), and oxygen (Martínez-Sosa \& Tierney, 2019: Huguet et al., 2017; Tierney et al., 2012). Since the identity of the source organisms remains unknown (Sinninghe Damsté et al.

45 2018), it is unclear how much impact these parameters have on the brGDGT response, or if their influence is environment-dependent, with different effects in soils and lakes.

A combination of their ubiquity, their response to changes in the environment, and their potential for preservation (Kemp et al. 2014 ) make brGDGTs a valuable tool for paleoclimate reconstructions. In the absence of pure culture studies, empirical calibrations are used to infer temperature and $\mathrm{pH}$ from brGDGT distributions. Global calibrations using the Hopmans et al. (2016) method exist for soils and peats (Dearing Crampton-Flood et al., 2020, Naafs et al. 2017a b). However, since soil calibrations underestimate temperature 55 when applied to lake sediments (Pearson et al., 2011; Tierney et al., 2010; Tierney \& Russell, 2009, Russell et al., 2018), these cannot be used for lacustrine applications. While several local (Loomis et al., 2012; Sun et al., 2011; Tierney et al. 2010) and global (Pearson et al., 2011) lake calibrations have been pre- 
sented, most of them were performed with the old analytical method and thus

did not fully separate the 5' and 6' isomers. Thus far, only local calibrations have been generated with the improved method (Russell et al., 2018, Dang et al. 2018, 2016a).

This work presents a dataset of 261 lake sediment samples from a wide range of locations and environmental regimes. We analyze the distribution

of brGDGTs and compare their relationship with environmental parameters to better understand this proxy system. We then use our dataset to construct a new global temperature calibration for lakes. Finally, we apply our new calibration to a previously published late Holocene lake core record in order to demonstrate its applicability.

\section{Methods}

\subsection{Samples}

We analyzed 158 new core top (cc. top $10 \mathrm{~cm}$ ) samples, spanning a wide range of Mean Annual Air Temperatures, precipitation regimes and $\mathrm{pH}$ (Fig. 1 and Supplementary Table A.1). Samples were processed in either the Uni75 versity of Arizona (UA) or the University of Wyoming (UW) (Supplementary Table A.1). All samples were freeze-dried for $48 \mathrm{~h}$, ground and homogenized in a solvent-cleaned mortar, and then extracted with an Accelerated Solvent Extraction (ASE) system (run at $1500 \mathrm{psi}, 100^{\circ} \mathrm{C}$, with dichloromethane:methanol (9:1)). At UW, the resulting total lipid extracts (TLEs) were first separated over an aminopropyl (LC-NH$\left.{ }_{2}\right)$ solid phase column using first DCM:Isopropanol (2:1), and then $4 \%$ acetic acid in DCM. GDGTs were recovered from the former fractions and subsequently separated over an activated silica gel column using Hexane, DCM, and $\mathrm{MeOH}$, from which GDGT were further isolated. At UA, the TLEs were eluted through a deactivated $\mathrm{SiO}_{2}$ column with hexane:ethyl acetate (1:2), and dried our samples under a $N_{2}$ stream. Both UA and UW samples were redissolved in hexane:isopropanol (99:1), and then passed through a $0.45 \mu m$ PTFE filter prior to being analyzed by HPLC. GDGTs were analyzed 
on an Agilent 1260 Infinity HPLC coupled to an Agilent 6120 single quadrupole mass spectrometer using two BEH HILIC silica columns $(2.1 \times 150$ mm, $1.7 \mu m$; Waters) and the methodology of Hopmans et al. (2016). We calculated peak areas using the MATLAB package software ORIGAmI (Fleming \& Tierney, 2016) and quantified brGDGTs by comparing the obtained peaks with a $C_{46}$ internal standard (Huguet et al. 2006) normalized to the mass of each sample. However, our statistical analyses are based on the fractional abundances of the brGDGTs, and not the absolute abundance (Supplementary Table A.2).

We supplemented our dataset with published values, including 65 samples from African lakes (Russell et al. 2018), and 38 Chinese lakes (Dang et al., 2018, 2016a). Collectively this work includes data from a total of 261 lakes. We further compare our results with 663 soil and peat samples from the Dearing Crampton-

Flood et al. (2020) calibration. It should be noted that some variability may be introduced in the dataset due to data deriving from different laboratories.

\subsection{Temperature and Precipitation Data}

․ Mean Annual Air Temperature (MAAT) and precipitation (MAP) for Dang et al. (2016a), Dang et al. (2018), and our sites were derived from either the PRISM product at a $800 \mathrm{~m}$ resolution, for samples within the continental USA and Alaska (PRISM Climate Group, Oregon State University), or from the CRU पS 4.01 product at a resolution of $0.5^{\circ}$ for the rest of the samples Osborn \& Jones, 2014). Values were obtained following the approach used by Dearing Crampton-Flood et al. (2020), where chordal distances were calculated for each sample. Multiple samples within the same lake were averaged and treated as one data point, except for samples from Lake Malawi due to its large size, in [Which case they were kept distinct. For the Russell et al. (2018) and Dearing Crampton-Flood et al. (2020) sites we used the parameters reported by the authors. Following Dearing Crampton-Flood et al. (2020) we also calculated the mean temperature of months above freezing (MAF). In the case of samples from Russell et al. (2018) we considered MAF to be equal to MAAT, as lakes in this region experience larger daily oscillations in temperature than seasonal, 
with freezing occurring only at night (Eggermont et al., 2007).

\section{3. $p H$ and Conductivity Data}

Water $\mathrm{pH}$ was measured on site for the UW samples (Supplementary Table A.1). For the remaining samples we collected $\mathrm{pH}$ and conductivity data from the literature when available (Supplementary Table A.1). For the rest of the dataset we used values reported by the authors in the original work (Dearing Crampton-Flood et al., 2020; Russell et al., 2018; Sinninghe Damsté et al., 2018 ,

125 Dang et al. 2016a).

\subsection{Empirical Orthogonal Function Analysis}

Empirical Orthogonal Function (EOF) analysis (Lorenz, 1956) was used to study the dataset in a reduced dimensional space. For this analysis, Singular Value Decomposition was applied to the centered covariance matrix for the fractional abundance of each brGDGT using the svd() $R$ function. Following Overland \& Preisendorfer (1982), a Rule N test was used to evaluate the significance of the obtained modes. This was performed in $\mathrm{R}$ using 10,000 Monte Carlo simulations and a $95 \%$ confidence interval.

\subsection{Indices}

brGDGTs are named with roman numerals $I, I I, I I I$ to denote whether they contain 4,5 , or 6 methyl groups, and lowercase $a, b, c$ to denote whether they contain 0,1 , or 2 cyclopentane rings. In addition, the ' symbol is used to indicate the 6-methyl isomers.

The $M B T_{5 M e}^{\prime}$ and $C B T^{\prime}$ indices are used to quantify the relative degree of methylation and the combined cyclization and isomerization response, respectively. These were calculated following De Jonge et al. (2014a):

$$
\begin{gathered}
M B T_{5 M e}^{\prime}=\frac{(I a+I b+I c)}{(I a+I b+I c+I I a+I I b+I I c+I I I a)} \\
C B T^{\prime}=\log _{10}\left(\frac{I c+I I a^{\prime}+I I b^{\prime}+I I c^{\prime}+I I I a^{\prime}+I I I b^{\prime}+I I I c^{\prime}}{I a+I I a+I I I a}\right)
\end{gathered}
$$


To further investigate the role of methylation on the brGDGT species we also calculated the $M B T$ index for the $6^{\prime}$ isomers as described in Dang et al. (2016b):

$$
M B T_{6 M e}^{\prime}=\frac{(I a+I b+I c)}{\left(I a+I b+I c+I I a^{\prime}+I I b^{\prime}+I I c^{\prime}+I I I a^{\prime}\right)}
$$

We also compute the isomer ratio proposed by De Jonge et al. (2014b) with the modifications made by Dang et al. (2016a), which represents the relative abundance of $6^{\prime}$ isomers:

$$
I R=\frac{\Sigma\left(I I^{\prime}\right)+\Sigma\left(I I I^{\prime}\right)}{\Sigma(I I)+\Sigma(I I I)+\Sigma\left(I I^{\prime}\right)+\Sigma\left(I I I^{\prime}\right)}
$$

Following Martínez-Sosa \& Tierney (2019), we calculated the fractional cyclization index $(f C)$ to quantify the relative cyclization of brGDGTs:

$$
f C=\frac{\Sigma(b)+2 \Sigma(c)+\Sigma\left(b^{\prime}\right)+2 \Sigma\left(c^{\prime}\right)}{\Sigma(a)+\Sigma(b)+\Sigma(c)+\Sigma\left(b^{\prime}\right)+\Sigma\left(c^{\prime}\right)} \times 0.5
$$

\subsection{Calibration}

150

For the calibration of the dataset, a Bayesian model was calculated in MATLAB using the BayMBT package (Dearing Crampton-Flood et al., 2020). We applied the baymbt_model() function using the same assumptions as Dearing Crampton-Flood et al. (2020). We identified outliers from the calibration by applying the rosnerTest function from the EnvStarts R package over the residuals Millard et al. 2018).

\subsection{Basin Pond core}

To test our calibration, we applied it to a downcore record of the $M B T_{5 M e}^{\prime}$ index from Basin Pond, ME, USA (Miller et al., 2018). This record spans 900 years and is one of the few lake records where the Hopmans et al. (2016) HPLC method is applied. We used the slope, intercept, and error variance parameters calculated from our global calibration and applied them to the Basin Pond $M B T_{5 M e}^{\prime}$ record through the baymbt_predict() MATLAB function. To estimate the prior value, we used the Russell et al. (2018) calibration to calculate 
a mean temperature for the record, and following (Dearing Crampton-Flood et al. 2020) we used a standard deviation of $10^{\circ} \mathrm{C}$.

We compared our reconstruction to temperature data from a nearby weather station located in Farmington, ME (Lawrimore et al., 2011), located $26 \mathrm{~km}$ northeast of Basin Pond. The station's instrumental record spans 128 years (1891-2019) which we used to calculate seasonal averages, MAAT and MAF.

\section{Results}

\subsection{Environmental Parameter Distribution}

$\mathrm{MAF}$ at our sites range from 1.6 to $28.1^{\circ} \mathrm{C}$ (Fig. 2a). $\mathrm{pH}$ values range from 4.3 to 10 (Fig. 2b), but only a few sites are truly acidic lakes $(\mathrm{pH}<6)$. MAP values range from 69.4 to $3818 \mathrm{~mm} /$ year (Fig. 2), with most of the data falling below $150 \mathrm{~mm} / \mathrm{month}$. The available conductivity data ranges from 0 to $20,000,000 \mu \mathrm{S} / \mathrm{cm}$ (Fig. 2d). While most of our lakes fall within the fresh water range $(<500 \mu \mathrm{S} / \mathrm{cm})$, some are hypersaline and/or alkaline lakes (i.e. Mono Lake, Lake Van, Big Soda Lake, and the Dead Sea). Our samples span a range of water depths from 0 to $377 \mathrm{~m}$ (Fig. 2p). The maximum depth of the lakes, where available, spans from 1 to $695 \mathrm{~m}$.

To assess the relationships between environmental factors, we calculated the Spearman correlation for each combination of factors (Table 1). While many combinations have small and/or insignificant correlation values, we also observe some strongly correlated parameters, such as $\mathrm{pH}$ and conductivity (0.62), MAF and conductivity (0.55), as well as precipitation and conductivity (-0.78).

\subsection{EOF Analysis and Correlation with Environmental Parameters}

Our EOF analysis on the brGDGT fractional abundances of the dataset suggests that only the first mode is statistically significant based on a Rule $\mathrm{N}$ test, and explains $86 \%$ of the variability. Even though our test deemed it insignificant, we retained Mode 2 for our analyses because the scree plot (not shown) suggests that it behaves differently from higher modes, and it explains $12 \%$ of 
the variance. To gain better insight on the possible environmental significance of each mode we examined the loading of each brGDGT (Fig. 3). BrGDGTs I $a$ and IIIa load prominently on Mode 1, with opposing signs (Fig. 3a). Some other minor contributors to the mode are $I I I a^{\prime}$ and $I I a$, with the same sign as $I I I a$; as well as $I I a^{\prime}$ and $I b$, which load with $I a$. The majority of the brGDGTs contributing to Mode 1 are used in the $M B T_{5 M e}^{\prime}$ calculation (Equation. 1), with the exception of the low-abundance molecules (i.e. Ic and IIc). Mode 2 on the other hand shows that $I a, I I a$ and $I I I a$ load with a similar weight and sign, while $I b, I I a^{\prime}, I I b, I I b^{\prime}$, and $I I I a^{\prime}$ contribute with the opposite sign (Fig. 3b). The brGDGT compounds contributing to this mode are all included in the $C B T^{\prime}$ index calculation (Equation 2).

We then compared the correlations between each mode and the available environmental parameters to understand the environmental processes that they might be reflecting (Table 2). Except for MAP, all variables show a significant correlation with Mode 1, with MAF and MAAT showing the highest correlations. MAF has a stronger correlation with Mode 1 than MAAT $(\rho=0.84$ and 0.81 , respectively). Mode 2 has significant correlations with most of the environmental parameters except water depth, but is most strongly correlated with MAP, $\mathrm{pH}$ and conductivity (0.53, -0.52 and -0.80 , respectively). Mode 2 has a small correlation with temperature (-0.31 and -0.18 for MAF and MAAT respectively).

\subsection{Comparison with brGDGT indices}

Since the two leading modes are influenced by a similar set of brGDGTs as the $M B T_{5 M e}^{\prime}$ and $C B T^{\prime}$ indices, respectively, we compared their correlations with temperature and $\mathrm{pH}$ (Figs. 4 and 5 . Mode 1 and $M B T_{5 M e}^{\prime}$ have very similar relationships with MAAT and MAF (Fig. (4), where MAF shows a stronger correlation with both parameters. $M B T_{5 M e}^{\prime}$ has a better correlation with MAF than with MAAT (0.86 and 0.82 respectively). Likewise, $C B T^{\prime}$ and Mode 2 have a comparable magnitude of correlation ( 0.53 and -0.54 respectively) with pH (Fig. 5b). Similar to Mode 2, $C B T^{\prime}$ has a significant correlation with 
all parameters but depth (Table 3). Furthermore, just as with Mode 2, $C B T^{\prime}$ shows a strong correlation with conductivity (0.81, Table 3).

We also tested the correlation between other previously reported indices

${ }_{225}\left(M B T_{6 M e}^{\prime}, I R\right.$, and $\left.f C\right)$ and the environmental parameters (Table 3). $M B T_{6 M e}^{\prime}$ has significant correlations with MAF, MAAT, MAP and conductivity. $I R$ has significant correlations with all parameters except for water depth, but correlates most strongly with MAF (0.64) and conductivity (0.76). $f C$ has significant correlations with all parameters except depth. Similar to $I R$, its strongest correlations are with MAF, MAAT, and conductivity. Nevertheless, none of these indices show a better correlation with MAF or $\mathrm{pH}$ and conductivity than $M B T_{5 M e}^{\prime}$ and $C B T^{\prime}$ respectively.

\subsection{Temperature Calibration}

Due to the overall better correlation between $M B T_{5 M e}^{\prime}$ with MAF, we chose this parameter to construct our calibration. Our Bayesian model has good fit to the data, with an $R^{2}=0.85$ and an $R M S E=2.7^{\circ} \mathrm{C}$ (Fig. 6a). This model covers a wide range of MAF temperatures, with an upper limit of $28.1^{\circ} \mathrm{C}$ and a lower limit of $0^{\circ} \mathrm{C}$ (due to the definition of MAF). MAF residuals from the calibration show no significant trend (Fig. 6p). Furthermore, these residuals show no spatial pattern (not shown) nor a significant correlation with $\mathrm{pH}$ or conductivity. However the residuals do have a weak but significant correlation $(p<0.05)$ with water depth $(\rho=0.26)$ and precipitation $(\rho=-0.16)$.

\subsection{Paleoclimate Application}

We applied the Bayesian calibration to the Basin Pond record (Fig. 7). Our reconstruction is similar $(r=0.99)$ to the one generated using the African lakes calibration Russell et al. (2018). A reconstruction using the regression of Dang et al. (2018) plots $\sim 3^{\circ} \mathrm{C}$ colder than the other two reconstructions, and lies outside of the $1 \sigma$ error of the Bayesian model. Dang et al. (2018) used a multiple linear regression based on fractional abundances of individual

brGDGTs to generate their calibration, which explains the lower correlation 
with our reconstruction $(r=0.73)$. To assess the validity of our reconstruction, we compared it with the monthly instrumental record from the weather station in Farmington, ME (26 km NE of Basin Pond). Our reconstruction plots close to MAF calculated from the station data, and as expected, above MAAT (Fig. $255 \quad 7 \mathrm{~b})$

\subsection{Comparison with Soils and Peats}

Finally, we compare the lake data compiled in this work with the soil and peat data from Dearing Crampton-Flood et al. (2020) (Fig. 8). In general, soils have higher $M B T_{5 M e}^{\prime}$ values than lakes for a given temperature. The Bayesian models for each dataset reflect this (Fig. 8, brown and green lines), showing distinctly different y-intercepts.

While at first glance, the slopes of regression lines for soils and lakes seem similar (0.024 and 0.030, respectively), a T-test (Long \& Rippeteau, 1974) performed on the distribution of slope values produced by BayMBT shows that they 265 are significantly different $(p<0.05)$. As observed by Dearing Crampton-Flood et al. (2020), the soil data have a wider spread at intermediate temperatures, a feature that does not appear to be as pronounced in the lake data.

We further compared the response of $C B T^{\prime}$ to $\mathrm{pH}$ in both datasets (Fig. 9). Linear regression indicates that soils and lakes have very different slopes $(0.50$ and 0.16 , respectively). While the regression for soils has an $R^{2}=0.73$, the $R^{2}$ of the lake regression is only 0.27 .

\section{Discussion}

\subsection{EOF Modes}

Our EOF analysis shows that a substantial amount of the variability in our lake dataset $(98 \%)$ can be explained by the first two modes. Assuming that these modes reflect single environmental factors, this suggests that other environmental parameters exert only a minor influence on the brGDGT proxy in lakes, at least on the global scale. Of the two modes, Mode 1 explains most 
of the variance $(86 \%)$ suggesting that the phenomena captured by this mode

\subsubsection{Mode 1}

We interpret Mode 1 to reflect the influence of temperature on brGDGT distributions. It strongly correlates with both MAAT and MAF, and has smaller correlations with $\mathrm{pH}$ and conductivity (Table 2). In addition, the brGDGTs ¡e active when lakes are frozen during the winter (Miller et al., 2018; Loomis et al. 2014). This agrees with previous calibration studies, which likewise show 
a better correlation with MAF in soils and peats and thus assume that the producers are not active at below-freezing temperatures (Dearing CramptonFlood et al. 2020; Naafs et al., 2017a).

\subsubsection{Mode 2}

We interpret Mode 2 as a reflection of water chemistry, as it is strongly correlated with lake $\mathrm{pH}$ and conductivity (Table2). Mode 2 does have a significant, but weak, correlation with $\operatorname{MAF}(\rho=-0.31)$, however this most likely reflects the correlation between MAF and both $\mathrm{pH}$ and conductivity present in our environmental data (Table 1). $C B T^{\prime}$, which has been used as a $\mathrm{pH}$ index, behaves similarly to Mode 2 (Table 3), and the two indices are influenced by the same group of brGDGTs (Fig. 3b and Equation 2), with a few exceptions ( $I b$ and $I I b$ participate in Mode 2). Interestingly, the correlations with conductivity (ca. 0.8) are much higher than with $\mathrm{pH}$ (ca. 0.5) for both Mode 2 and $C B T^{\prime}$, which could suggest that brGDGT distributions are sensitive to anion concentrations in addition to the acidity of the water. However, since $\mathrm{pH}$ and conductivity are closely linked, it is difficult to discern a causal relationship from the strength of these correlations. The strong relationship with conductivity could simply reflect the fact that this measurement is easier to make in the field than $\mathrm{pH}$, and potentially more accurate (since $\mathrm{pH}$ meters need to be calibrated). Furthermore, we have fewer measurements of conductivity $(N=119)$ than $\mathrm{pH}(N=178)$, which could inflate the correlation value for conductivity.

While Mode 2 suggests that water chemistry affects brGDGT distributions, this mode only accounts for $12 \%$ of the variance in the dataset, and it is not significant at the $p<0.05$ threshold. This might explain the ambiguous $\mathrm{pH}$ response observed in other empirical lake studies (Russell et al., 2018, Sun et al. 2011), as well as in controlled incubations of lake water (Martínez-Sosa et al. 2020). In contrast, $\mathrm{pH}$ has been shown to exert a clear influence on peat (Naafs et al. 2017b and soil brGDGT distributions Naafs et al. 2017a; Xiao et al. 2015). Given that our dataset spans a large $\mathrm{pH}$ range (4.3-10) it is unlikely that the weak relationship we observe is due to sampling bias. It is possible that the 
strong correlation with $\mathrm{pH}$ in soils and peats partly reflects an effect of soil

vironments. Another possibility, supported by previous works (De Jonge et al. 2019, Weber et al. 2018), is that the microbial communities responsible for producing brGDGTs in soils and lakes are different, and thus have characteristic responses to temperature and $\mathrm{pH}$.

345 developing a $\mathrm{pH}$ or conductivity calibration for lakes.

\subsection{Additional indices}

$I R$ and $f C$, indices for the relative degree of isomerization and cyclization, show moderately strong correlations with MAF, conductivity, and $\mathrm{pH}$ ( $\rho=0.65$, temperature supports our previous microcosm results, which similarly indicate that isomerization and cyclization have thermal sensitivity (Martínez-Sosa et al. 2020). However, since water chemistry exerts an equal (if not larger, in the case of $I R$ ) influence on these indices, they are not as useful as $M B T_{5 M e}^{\prime}$ for paleothermometry. Conversely, the influence of temperature limits the utility of $I R$ and $f C$ for water chemistry reconstruction ( $\mathrm{pH}$ or conductivity). As discussed, the sensitivity of brGDGTs to water chemistry is better captured by $C B T^{\prime}$, which is a combined metric of isomerization and cyclization.

\subsection{Temperature Calibration}

360

Our EOF analysis demonstrates that temperature is the primary influence on brGDGT distribution in lakes on the global scale. Furthermore, our results suggest that the use of MAF, as an alternative to MAAT, improves the correlation with $M B T_{5 M e}^{\prime}$, as it accounts for the seasonally biased response observed in the mid to high latitudes, which likely reflects reduced microbial activity (Dearing Crampton-Flood et al., 2020). This allows us to construct a universal lakes calibration for paleoclimate applications, using the Bayesian model developed by Dearing Crampton-Flood et al. (2020). The Bayesian approach 
allows us to present MAF as the independent variable and, since the Bayesian method generates an ensemble of possible regression parameters, the calibration accounts for both parameter and residual uncertainties. Furthermore, Dearing Crampton-Flood et al. (2020) showed that the use of ordinary least squares regression with MAF as the dependent variable leads to regression dilution, thus making the Bayesian model a more suitable approach.

Our calibration has an $R^{2}=0.85$, comparable with previous calibrations (Dearing Crampton-Flood et al., 2020, Naafs et al., 2017a, De Jonge et al. 2014a) but lower than the one presented by Russell et al. (2018) of 0.92. This likely reflects the larger number of samples (spanning a greater diversity of climate and geography) included in this work, although both calibrations have comparable RMSE values $\left(2.4^{\circ} \mathrm{C}\right.$ and $\left.2.7^{\circ} \mathrm{C}\right)$. Our calibration residuals do not show any trends with temperature (Fig. 6p), as expected from the model.

■ In the process of developing the temperature calibration, a Rosner test ( Rosner, 1983) identified six outliers (Fig. 6a), which we ultimately excluded from the final calibration. These outliers come from all three studies, which suggests they are not related to laboratory-specific procedures. Rather, they seem to be related to extreme water chemistry - five out of six of the outliers come from alkaline, saline lakes. Two of the outlying samples are from the western USA: Mono Lake and Big Soda Lake. Mono lake has a pH of 9.7 and conductivity of $80,000 \mu \mathrm{S} / \mathrm{cm}$ (Jiang et al., 2004, Domagalski et al., 1989), and Big Soda lake has a pH of 9.7 and conductivity of about 20,000 $\mu \mathrm{S} / \mathrm{cm}$ (Priscu et al. 390 1982, Kharaka et al., 1984). Big Soda Lake also has an unusual dichothermal water column profile as a consequence of its high salt content (Priscu et al. 1982), which might influence both the microbial communities present and the brGDGT response. Two additional outliers come from Chile: Laguna Amarga and Laguna del Negro Francisco. Both are shallow (4.1 and $1 \mathrm{~m}$, maximum depth respectively) endorheic basins. Laguna Amarga has a pH of 8.4 and a conductivity of 52,367 $\mu \mathrm{S} / \mathrm{cm}$ ) (Campos et al. 1995), while Laguna del Negro Francisco is a hypersaline $(80,000 \mu \mathrm{S} / \mathrm{cm})$ lagoon (Grosjean et al., 1997). A fifth outlier is Lake Qinghai, in China. Qinghai is also alkaline and saline, with 
a conductivity of $19,970 \mu \mathrm{S} / \mathrm{cm}$ and a $\mathrm{pH}$ of 8.7 (Yang et al., 2003). The sixth

its conductivity is $600 \mu \mathrm{S} / \mathrm{cm}$. However, it is alkaline, with a pH of 8.9 (Gelorini et al. 2011).

While the observed outliers are nearly all highly alkaline/saline lakes, it is important to note that there are other lakes in our dataset that have either high $\mathrm{pH}$ (i.e. Lake Van with $\mathrm{pH}=9.8$ ) or high conductivity (i.e. Lake Daihai, $15,647 \mu S / \mathrm{cm}$ ) and fall well within the confidence interval of our calibration. Our calibration also includes a sample from the Dead Sea (Neugebauer et al. 2014), which has an extremely high conductivity of $202 \mathrm{mS} / \mathrm{cm}$ (Akawwi et al. 2011 ) but a $\mathrm{pH}$ of only 6 (Sass \& Ben-Yaakov, 1977). This sample, while on is the combined effect of salinity and alkalinity that leads to outlying brGDGT distributions. Our observation that alkaline, saline lakes tend to have outlying brGDGT distributions is in line with results presented by Tierney et al. (2010), in which lakes from Africa with conductivities above 30,000 $\mu \mathrm{S} / \mathrm{cm}$ showed distinct brGDGT distributions compared with the rest of the dataset $(<5,900 \mu \mathrm{S} / \mathrm{cm})$.

There are several possible explanations for the deviant behavior of brGDGT distributions in alkaline, saline lakes. For one, these types of lakes have a restricted bacterial diversity (Humayoun et al., 2003), so it seems likely that the microbial community responsible for the brGDGT production in these environments is distinct from the communities found in more neutral, freshwater lakes, and thus may have a completely different sensitivity to environmental perturbations. Alternatively, the water chemistry of these environments may be extreme enough to directly influence brGDGT methylation. Excluding Mahuhura, all of the outliers have higher-than-expected $M B T_{5 M e}^{\prime}$ for their given temperature, suggesting that less methylated brGDGTs are favored under alkaline, saline conditions. While higher than estimated $M B T_{5 M e}^{\prime}$ values might also indicate that in these extreme water chemistries, there is a preferential loss of the more methylated compounds during diagenesis, we also observe higher $I R$ values in 

inputs. or in situ production from a distinct producer. Given the limited sample size of these extreme environments, it is difficult to generalize, but the observed trend agrees with previous work (Tierney et al., 2010), and should be further explored.

435 distributed values of $M B T_{5 M e}^{\prime}$ demonstrates that brGDGT response to temperature is mostly unaffected by additional physical and chemical factors. Further evidence of this comes from the weak and statistically insignificant correlations between the model residuals and most environmental parameters $(\rho<0.05$, not depth $(\rho=0.26)$, as well as with precipitation $(\rho=-0.16)$. Notably, the correlation with water depth is significant only for shallow $(<20 \mathrm{~m})$ lakes $(\rho=0.25$, Fig. 10a), not deep lakes $(\rho=-0.17$, Fig. 10a). The correlation is such that the shallowest lakes have negative residuals, indicating that brGDGTs predict found that the correlation is stronger $(\rho=0.41)$ if we consider only the temperate lakes $\left(>35^{\circ} \mathrm{N}\right.$ and $\left.\mathrm{S}\right)$ within our data set $(n=111$; Fig. $10 \mathrm{p})$, and is not significant for the shallow tropical lakes $(n=96)$. We attribute this to an increased influence of thermal variability in temperate lakes. Unlike tropical lakes, which experience a restricted seasonal changes in air temperature (Russell et al. 2018), temperate lakes - especially shallow ones - are subject to large swings in temperature both seasonally and diurnally. Thus the apparent influence of water depth on brGDGT distributions in shallow temperate lakes could reflect water temperatures that seasonally or diurnally exceed MAF. Alternatively, the observed warm bias could indicate greater input of soil-derived brGDGTs in shallow lake systems. However, were this the case, we would expect to see a similar phenomenon in shallow tropical lakes, where there is a clear offset between soil and lake brGDGTs (Tierney et al. 2010; Russell et al. 2018). A third possibility is that the trend from negative to positive residuals 460 reflects an increasing contribution of in situ production at depth (i.e., at or near 
the thermocline), which would result in lower inferred temperatures in deeper lakes. However, if this were the primary explanation, we would expect to see the residual trend persist in deeper lakes, where the thermocline temperatures can be much lower than surface temperatures. Although it is a relatively minor effect, This observed influence of water depth on lacustrine brGDGTs deserves further investigation.

\subsection{Paleoclimate Application}

When we apply our new temperature calibration to brGDGTs at Basin Pond, awe obtain temperatures that are on average $\sim 0.7^{\circ} \mathrm{C}$ lower than the Russell

470 et al. (2018) calibration (Fig. 77). However, since our calibration includes a larger variety of geographic and environmental settings, including samples from the northeast USA, it might be more appropriate for the Basin Pond site. Even though the lake core has a lower resolution than the instrumental record, it is impressive that MAF from the latter falls within the $1 \sigma$ range of 475 our reconstruction, with an average difference of $1^{\circ} \mathrm{C}$. This suggests that our new global calibration provides reasonably accurate estimates of MAF.

\subsection{Soils vs Lakes}

$M B T_{5 M e}^{\prime}$ in soils and peats (Dearing Crampton-Flood et al. 2020) has a reduced sensitivity to temperature (i.e., lower slope) than lakes (Figure 8). There

480 is also a large difference in the y-intercept terms between the soils and lakes BayMBT model, which reflects the tendency of lacustrine environments to have lower $M B T_{5 M e}^{\prime}$ values compared with soils at a given temperature. This effect has been previously reported as a "cold bias" when applying soil calibration to lake records (Russell et al., 2018; Tierney et al., 2010). Lipid and sequencing analyses have shown that the microbial communities responsible for the production of brGDGTs in soils and lakes might be different (De Jonge et al., 2019. Weber et al. 2018, 2015), a factor which could explain this consistent offset between both datasets. Alternatively, it is possible that interfering factors, such as soil moisture (Dang et al. 2016b) could be affecting the sensitivity of brGDGTs 

low $20^{\circ} \mathrm{C}$. This could partially reflect input of soil-derived GDGTs into our lake sites, a factor that we cannot constrain. Nevertheless, our samples have a lower dispersion $\left(\mathrm{RMSE}=2.7^{\circ} \mathrm{C}\right)$ compared with soils $\left(\mathrm{RMSE}=3.8^{\circ} \mathrm{C}\right)$, which could imply that soil input has a relatively small influence on lacustrine brGDGTs. calibration that includes soils, peats, and lakes (Fig. 8 solid black line). We observe that the $R^{2}$ is lower than the observed for both independent calibrations (0.67), and the RMSE increases $\left(4.2^{\circ} \mathrm{C}\right)$, nevertheless these values are within the range reported for the soil calibration (Dearing Crampton-Flood et al.

and lakes ( $\rho=0.82$, and 0.53 respectively). Given this observation, and the fact that water chemistry explains only $12 \%$ of the variance in our brGDGT data, we do not recommend using lacustrine brGDGTs to reconstruct $\mathrm{pH}$.

\section{Conclusions}

In this work we present a globally distributed dataset of brGDGTs in lacustrine core top sediments. In agreement with previous empirical and laboratory studies we find that temperature, particularly the mean temperature above freezing, has the largest influence on the brGDGT response. Our EOF analysis 
corroborates that the molecules involved in the $M B T_{5 M e}^{\prime}$ calculation show the best correlation to this parameter. Water chemistry, either $\mathrm{pH}$ or conductivity, exerts a weak influence on brGDGT distributions, which leads us to recommend against the use of brGDGT distributions to reconstruct water $\mathrm{pH}$.

Our global Bayesian calibration improves on previous works by expanding the sample size and number of locations, accounting for uncertainties in both the calibration parameters and residual error, as well as resolving the regression dilution bias that emerges in traditional ordinary least squares models. While care should be taken when working with highly alkaline, hypersaline systems, the Bayesian lake calibration presented here is robust across a wide range of environmental regimes. The lakes BayMBT model has a steeper slope and lower 530 intercept than the soils model, which suggests that soil and lake-specific calibrations should be used whenever possible in order to obtain the most accurate temperature estimation. However, our naive calibration provides an alternative option for deep-time applications where the paleo-environment may be unclear.

\section{Research Data}

Data associated with article is available on the Pangaea database [link will be inserted when ready].

\section{Acknowledgments}

We thank the LacCore facility for providing the samples used in this work. We also acknowledge Patrick Murphy for his assistance with the lipid analysis, and Darrell Kaufman for making the Alaskan surface sediments available. This research was funded by the National Science Foundation, grant EAR-1603674 and grant EPS-1655726, and by CONACYT through the student scholarship 440897. 


\section{References}

${ }_{545}$ Akawwi, E., Al-Zoubi, A., \& Abueladas, A.-R. (2011). Using electrical conductivity for locating the submarine groundwater discharge along the eastern shores of the Dead Sea-Jordan. Int. Multidiscip. Sci. Geoconf. SGEM, 1, 653.

Campos, H., Soto, D., Parra, O., Steffen, W., \& Aguero, G. (1995). Limnological studies of Amarga lagoon, Chile: a saline lake in Patagonian South America. Int. J. Salt Lake Res., 4, 301-314.

Dang, X., Ding, W., Yang, H., Pancost, R. D., Naafs, B. D. A., Xue, J., Lin, X., Lu, J., \& Xie, S. (2018). Different temperature dependence of the bacterial brGDGT isomers in 35 Chinese lake sediments compared to that in soils. Org. Geochem., 119, 72-79.

555 Dang, X., Xue, J., Yang, H., \& Xie, S. (2016a). Environmental impacts on the distribution of microbial tetraether lipids in Chinese lakes with contrasting $\mathrm{pH}$ : Implications for lacustrine paleoenvironmental reconstructions. Sci. China Earth Sci., 59, 939-950.

Dang, X., Yang, H., Naafs, B. D. A., Pancost, R. D., \& Xie, S. (2016b). Evidence of moisture control on the methylation of branched glycerol dialkyl glycerol tetraethers in semi-arid and arid soils. Geochim. Cosmochim. Acta, 189, $24-36$.

De Jonge, C., Hopmans, E. C., Stadnitskaia, A., Rijpstra, W. I. C., Hofland, R., Tegelaar, E., \& Sinninghe Damsté, J. S. (2013). Identification of novel penta-and hexamethylated branched glycerol dialkyl glycerol tetraethers in peat using HPLC-MS2, GC-MS and GC-SMB-MS. Org. Geochem., 54, 7882.

De Jonge, C., Hopmans, E. C., Zell, C. I., Kim, J.-H., Schouten, S., \& Sinninghe Damsté, J. S. (2014a). Occurrence and abundance of 6-methyl branched glycerol dialkyl glycerol tetraethers in soils: Implications for palaeoclimate reconstruction. Geochim. Cosmochim. Acta, 141, 97-112. 
De Jonge, C., Radujković, D., Sigurdsson, B. D., Weedon, J. T., Janssens, I., \& Peterse, F. (2019). Lipid biomarker temperature proxy responds to abrupt shift in the bacterial community composition in geothermally heated soils. Org. Geochem., .

De Jonge, C., Stadnitskaia, A., Hopmans, E. C., Cherkashov, G., Fedotov, A., \& Sinninghe Damsté, J. S. (2014b). In situ produced branched glycerol dialkyl glycerol tetraethers in suspended particulate matter from the Yenisei River, Eastern Siberia. Geochim. Cosmochim. Acta, 125, 476-491.

Dearing Crampton-Flood, E., Tierney, J. E., Peterse, F., Kirkels, F. M., \& Damsté, J. S. S. (2020). Baymbt: A bayesian calibration model for branched glycerol dialkyl glycerol tetraethers in soils and peats. Geochim. Cosmochim. Acta, 268, 142-159.

Domagalski, J. L., Orem, W. H., \& Eugster, H. P. (1989). Organic geochemistry 585 and brine composition in Great Salt, Mono, and Walker Lakes. Geochim. Cosmochim. Acta, 53, 2857-2872.

Eggermont, H., Russell, J. M., Schettler, G., Van Damme, K., Bessems, I., \& Verschuren, D. (2007). Physical and chemical limnology of alpine lakes and pools in the Rwenzori Mountains (Uganda-DR Congo). Hydrobiologia, 592, $151-173$.

Fleming, L. E., \& Tierney, J. E. (2016). An automated method for the determination of the $T E X_{86}$ and paleotemperature indices. Org. Geochem., 92, $84-91$.

Gelorini, V., Verbeken, A., van Geel, B., Cocquyt, C., \& Verschuren, D. (2011). Modern non-pollen palynomorphs from East African lake sediments. Rev. Palaeobot. Palynol., 164, 143-173.

Grosjean, M., Valero-Garcés, B. L., Geyh, M. A., Messerli, B., Schotterer, U., Schreier, H., \& Kelts, K. (1997). Mid-and late-Holocene limnogeology of La- 
guna del Negro Francisco, northern Chile, and its palaeoclimatic implications. The Holocene, 7, 151-159.

Hopmans, E. C., Schouten, S., \& Sinninghe Damsté, J. S. (2016). The effect of improved chromatography on GDGT-based palaeoproxies. Org. Geochem., 93, 1-6.

Huguet, A., Meador, T. B., Laggoun-Défarge, F., Könneke, M., Wu, W., Derenne, S., \& Hinrichs, K.-U. (2017). Production rates of bacterial tetraether lipids and fatty acids in peatland under varying oxygen concentrations. Geochim. Cosmochim. Acta, 203, 103-116.

Huguet, C., Hopmans, E. C., Febo-Ayala, W., Thompson, D. H., Sinninghe Damsté, J. S., \& Schouten, S. (2006). An improved method to determine the absolute abundance of glycerol dibiphytanyl glycerol tetraether lipids. Org. Geochem., 37, 1036-1041.

Humayoun, S. B., Bano, N., \& Hollibaugh, J. T. (2003). Depth distribution of microbial diversity in Mono Lake, a meromictic soda lake in California. Appl. Environ. Microbiol., 69, 1030-1042. D. A., Lunt, D. J., Valdes, P. J., \& Pancost, R. D. (2019). Terrestrial environmental change across the onset of the PETM and the associated impact on biomarker proxies: A cautionary tale. Global Planet. Change, 181, 102991.

Jiang, S., Steward, G., Jellison, R., Chu, W., \& Choi, S. (2004). Abundance, distribution, and diversity of viruses in alkaline, hypersaline Mono Lake, California. Microb. Ecol., 47, 9-17.

Kemp, D. B., Robinson, S. A., Crame, J. A., Francis, J. E., Ineson, J., Whittle, R. J., Bowman, V., \& O'Brien, C. (2014). A cool temperate climate on the Antarctic Peninsula through the latest Cretaceous to early Paleogene. Geology, 42, 583-586. 
Kharaka, Y. K., Robinson, S. W., Law, L. M., \& Carothers, W. W. (1984).

Hydrogeochemistry of Big Soda Lake, Nevada: an alkaline meromictic desert lake. Geochim. Cosmochim. Acta, 48, 823-835.

Lawrimore, J. H., Menne, M. J., Gleason, B. E., Williams, C. N., Wuertz, D. B., Vose, R. S., \& Rennie, J. (2011). An overview of the Global Historical Climatology Network monthly mean temperature data set, version 3. J. Geophys. Res., 116.

Long, A., \& Rippeteau, B. (1974). Testing contemporaneity and averaging radiocarbon dates. Am. Antiq., 39, 205-215.

Loomis, S. E., Russell, J. M., Heureux, A. M., D’Andrea, W. J., \& Damsté, J. S. S. (2014). Seasonal variability of branched glycerol dialkyl glycerol tetraethers (brGDGTs) in a temperate lake system. Geochim. Cosmochim. Acta, 144, 173-187.

Loomis, S. E., Russell, J. M., Ladd, B., Street-Perrott, F. A., \& Damsté, J. S. S. (2012). Calibration and application of the branched GDGT temperature proxy on East African lake sediments. Earth Planet. Sci. Lett., 357, 277-288.

Lorenz, E. N. (1956). Empirical orthogonal functions and statistical weather prediction. Statistical Forecasting Project Rep. 1,MIT Department of Meteorology.

${ }_{645}$ Martínez-Sosa, P., \& Tierney, J. E. (2019). Lacustrine brGDGT response to microcosm and mesocosm incubations. Org. Geochem., 127, 12-22.

Martínez-Sosa, P., Tierney, J. E., \& Meredith, L. K. (2020). Controlled lacustrine microcosms show a brGDGT response to environmental perturbations. Org. Geochem., (p. 104041).

Millard, S. P., Kowarik, M. A., \& Imports, M. (2018). Package 'EnvStats'.

Miller, D. R., Habicht, M. H., Keisling, B. A., Castañeda, I. S., \& Bradley, R. S. (2018). A 900-year New England temperature reconstruction from in situ sea- 
sonally produced branched glycerol dialkyl glycerol tetraethers (brGDGTs). Clim. Past, 14, 1653-1667.

Naafs, B., Gallego-Sala, A., Inglis, G., \& Pancost, R. (2017a). Refining the global branched glycerol dialkyl glycerol tetraether (brGDGT) soil temperature calibration. Org. Geochem., 106, 48-56.

Naafs, B., Inglis, G., Zheng, Y., Amesbury, M., Biester, H., Bindler, R., Blewett, J., Burrows, M., del Castillo Torres, D., Chambers, F., Cohen, A., Evershed, R., Feakins, S., Gałka, M., Gallego-Sala, A., Gandois, L., Gray, D., Hatcher, P., Coronado, E. H., Hughes, P., Huguet, A., Könönen, M., LaggounDéfarge, F., Lähteenoja, O., Lamentowicz, M., Marchant, R., McClymont, E., Pontevedra-Pombal, X., Ponton, C., Pourmand, A., Rizzuti, A., Rochefort, L., Schellekens, J., Vleeschouwer, F. D., \& Pancost, R. (2017b). Introducing global peat-specific temperature and $\mathrm{pH}$ calibrations based on brGDGT bacterial lipids. Geochim. Cosmochim. Acta, 208, 285-301.

Neugebauer, I., Brauer, A., Schwab, M. J., Waldmann, N. D., Enzel, Y., Kitagawa, H., Torfstein, A., Frank, U., Dulski, P., Agnon, A. et al. (2014). Lithology of the long sediment record recovered by the ICDP Dead Sea Deep Drilling Project (DSDDP). Quat. Sci. Rev., 102, 149-165.

Osborn, T., \& Jones, P. (2014). The CRUTEM4 land-surface air temperature data set: construction, previous versions and dissemination via Google Earth. Earth Syst. Sci. Data, 6, 61-68.

Overland, J. E., \& Preisendorfer, R. (1982). A significance test for principal 675 components applied to a cyclone climatology. Mon. Weather Rev., 110, 1-4.

Pearson, E. J., Juggins, S., Talbot, H. M., Weckström, J., Rosén, P., Ryves, D. B., Roberts, S. J., \& Schmidt, R. (2011). A lacustrine GDGT-temperature calibration from the Scandinavian Arctic to Antarctic: Renewed potential for the application of GDGT-paleothermometry in lakes. Geochim. Cosmochim. Acta, 75, 6225-6238. 
Peterse, F., Kim, J.-H., Schouten, S., Kristensen, D. K., Koç, N., \& Damsté, J. S. S. (2009). Constraints on the application of the MBT/CBT palaeothermometer at high latitude environments (Svalbard, Norway). Org. Geochem., 40, 692-699.

Priscu, J., Axler, R., Carlton, R., Reuter, J., Arneson, P., \& Goldman, C. (1982). Vertical profiles of primary productivity, biomass and physicochemical properties in meromictic Big Soda Lake, Nevada, USA. Hydrobiologia, 96, 113-120.

PRISM Climate Group, Oregon State University (). http://prism.oregonstate.edu. Created 4 Dec 2018.

Rosner, B. (1983). Percentage points for a generalized ESD many-outlier procedure. Technometrics, 25, 165-172.

Russell, J. M., Hopmans, E. C., Loomis, S. E., Liang, J., \& Damsté, J. S. S. (2018). Distributions of 5- and 6-methyl branched glycerol dialkyl glycerol tetraethers (brGDGTs) in East African lake sediment: Effects of temperature, $\mathrm{pH}$, and new lacustrine paleotemperature calibrations. Org. Geochem., 117, $56-69$.

Sass, E., \& Ben-Yaakov, S. (1977). The carbonate system in hypersaline solutions: Dead Sea brines. Mar. Chem., 5, 183-199.

Sinninghe Damsté, J. S., Hopmans, E. C., Pancost, R. D., Schouten, S., \& Geenevasen, J. A. (2000). Newly discovered non-isoprenoid glycerol dialkyl glycerol tetraether lipids in sediments. Chem. Commun., (pp. 1683-1684).

Sinninghe Damsté, J. S., Rijpstra, W. I. C., Foesel, B. U., Huber, K. J., Overmann, J., Nakagawa, S., Kim, J. J., Dunfield, P. F., Dedysh, S. N., \& Vil705 lanueva, L. (2018). An overview of the occurrence of ether-and ester-linked iso-diabolic acid membrane lipids in microbial cultures of the Acidobacteria: Implications for brGDGT paleoproxies for temperature and $\mathrm{pH}$. Org. Geochem., 124, 63-76. 
Sinninghe Damsté, J. S., Rijpstra, W. I. C., Hopmans, E. C., Weijers, J. W.,

Foesel, B. U., Overmann, J., \& Dedysh, S. N. (2011). 13, 16-Dimethyl octacosanedioic acid (iso-diabolic acid), a common membrane-spanning lipid of Acidobacteria subdivisions 1 and 3. Appl. Environ. Microbiol., 77, 4147-4154.

Sun, Q., Chu, G., Liu, M., Xie, M., Li, S., Ling, Y., Wang, X., Shi, L., Jia, G., \& Lue, H. (2011). Distributions and temperature dependence of branched glycerol dialkyl glycerol tetraethers in recent lacustrine sediments from China and Nepal. JGR, 116 .

Tierney, J. E., \& Russell, J. M. (2009). Distributions of branched GDGTs in a tropical lake system: implications for lacustrine application of the MBT/CBT paleoproxy. Org. Geochem., 40, 1032-1036.

720 Tierney, J. E., Russell, J. M., Eggermont, H., Hopmans, E., Verschuren, D., \& Sinninghe Damsté, J. S. (2010). Environmental controls on branched tetraether lipid distributions in tropical East African lake sediments. Geochim. Cosmochim. Acta, 74, 4902-4918.

Tierney, J. E., Schouten, S., Pitcher, A., Hopmans, E. C., \& Sinninghe Damsté, J. S. (2012). Core and intact polar glycerol dialkyl glycerol tetraethers (GDGTs) in Sand Pond, Warwick, Rhode Island (USA): Insights into the origin of lacustrine GDGTs. Geochim. Cosmochim. Acta, 77, 561-581.

Weber, Y., De Jonge, C., Rijpstra, W., Hopmans, E. C., Stadnitskaia, A., Schubert, C. J., Lehmann, M. F., Sinninghe Damsté, J. S., \& Niemann, H. 730 (2015). Identification and carbon isotope composition of a novel branched GDGT isomer in lake sediments: Evidence for lacustrine branched GDGT production. Geochim. Cosmochim. Acta, 154, 118-129.

Weber, Y., Sinninghe Damsté, J. S., Zopfi, J., De Jonge, C., Gilli, A., Schubert, C. J., Lepori, F., Lehmann, M. F., \& Niemann, H. (2018). Redox-dependent niche differentiation provides evidence for multiple bacterial sources of glycerol tetraether lipids in lakes. Proc. Natl. Acad. Sci. U.S.A, 115, 10926-10931. 
Weijers, J. W., Panoto, E., van Bleijswijk, J., Schouten, S., Rijpstra, W. I. C., Balk, M., Stams, A. J., \& Sinninghe Damsté, J. S. (2009). Constraints on the biological source $(\mathrm{s})$ of the orphan branched tetraether membrane lipids. Geomicrobiol. J., 26, 402-414.

Weijers, J. W., Schouten, S., van den Donker, J. C., Hopmans, E. C., \& Sinninghe Damsté, J. S. (2007). Environmental controls on bacterial tetraether membrane lipid distribution in soils. Geochim. Cosmochim. Acta, 71, 703713.

${ }_{745}$ Weijers, J. W., Schouten, S., Hopmans, E. C., Geenevasen, J. A., David, O. R., Coleman, J. M., Pancost, R. D., \& Sinninghe Damsté, J. S. (2006). Membrane lipids of mesophilic anaerobic bacteria thriving in peats have typical archaeal traits. Environ. Microbiol., 8, 648-657.

Xiao, W., Wang, Y., Zhou, S., Hu, L., Yang, H., \& Xu, Y. (2016). Ubiquitous production of branched glycerol dialkyl glycerol tetraethers (brGDGTs) in global marine environments: a new source indicator for brGDGTs. Biogeosciences, 13, 5883-5894.

Xiao, W., Xu, Y., Ding, S., Wang, Y., Zhang, X., Yang, H., Wang, G., \& Hou, J. (2015). Global calibration of a novel, branched GDGT-based soil pH proxy. Org. Geochem., 89, 56-60.

Yang, X., Kamenik, C., Schmidt, R., \& Wang, S. (2003). Diatom-based conductivity and water-level inference models from eastern Tibetan (QinghaiXizang) Plateau lakes. J. Paleolimnol., 30, 1-19.

Zell, C., Kim, J.-H., Moreira-Turcq, P., Abril, G., Hopmans, E. C., Bonnet, M.-P., Sobrinho, R. L., \& Sinninghe Damsté, J. S. (2013). Disentangling the origins of branched tetraether lipids and crenarchaeol in the lower Amazon River: Implications for GDGT-based proxies. Limnol. Oceanogr., 58, 343353. 
Zhou, H., Hu, J., Spiro, B., Tang, J. et al. (2014). Glycerol dialkyl glycerol tetraethers in surficial coastal and open marine sediments around China: Indicators of sea surface temperature and effects of their sources. Palaeogeogr. Palaeoclimatol. Palaeoecol., 395, 114-121. 


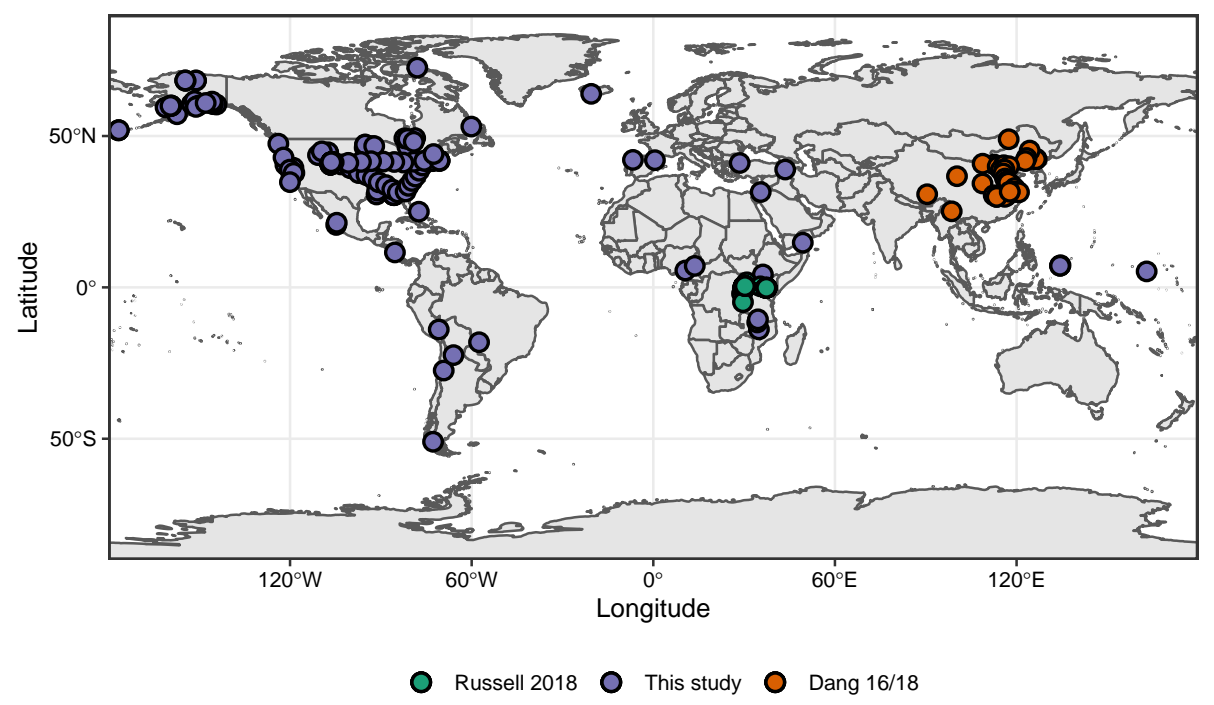

Figure 1: World map showing the location of the samples included in this dataset. Samples are color coded based to their source. Purple points represent samples from our dataset, Green points are samples derived from Russell et al. (2018). Orange samples represent sites included in Dang et al. (2018) and Dang et al. (2016a). 

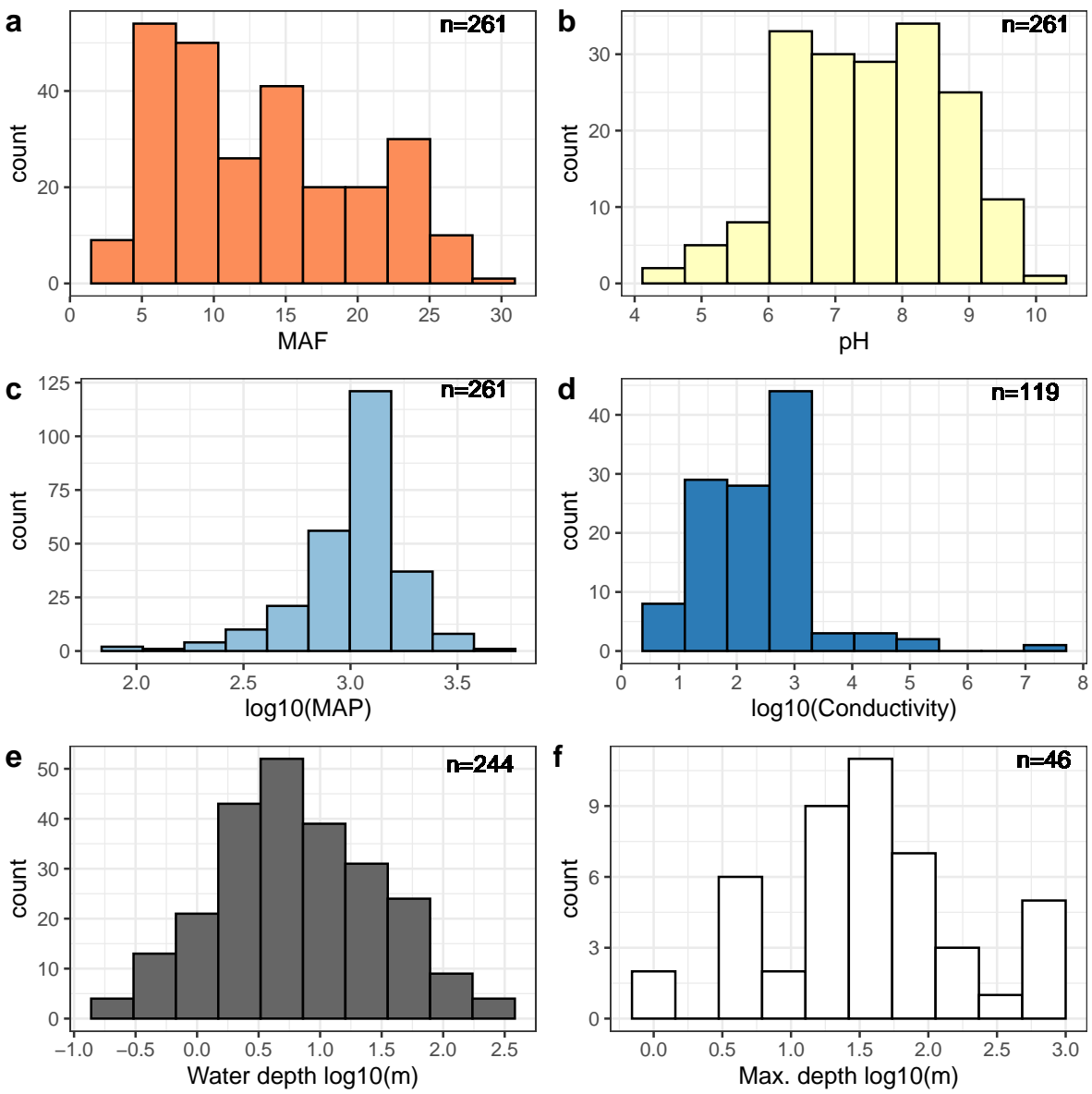

Figure 2: Distribution of environmental parameters in the complete dataset, number of samples with available data shown on top right. a) Mean Temperature of Months Above Freezing $\left.\left.\left(>0^{\circ} \mathrm{C}\right), \mathrm{b}\right) \mathrm{pH}, \mathrm{c}\right)$ Mean annual precipitation $\left.(\mathrm{mm} / \mathrm{month}), \mathrm{d}\right)$ Conductivity, e) Water Depth, and f) Maximum lake depth. 
a

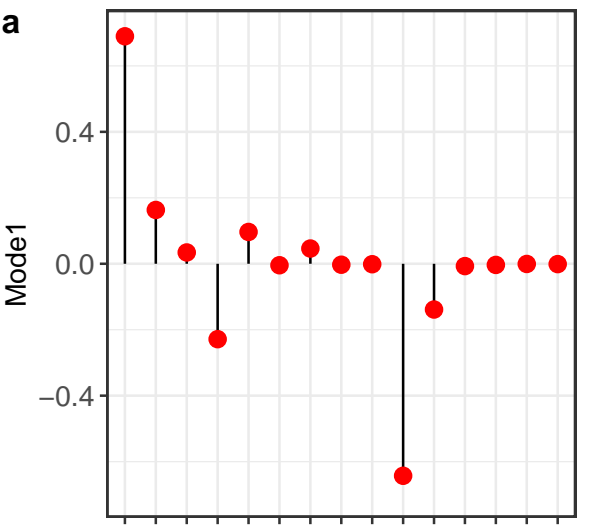

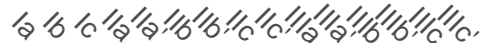

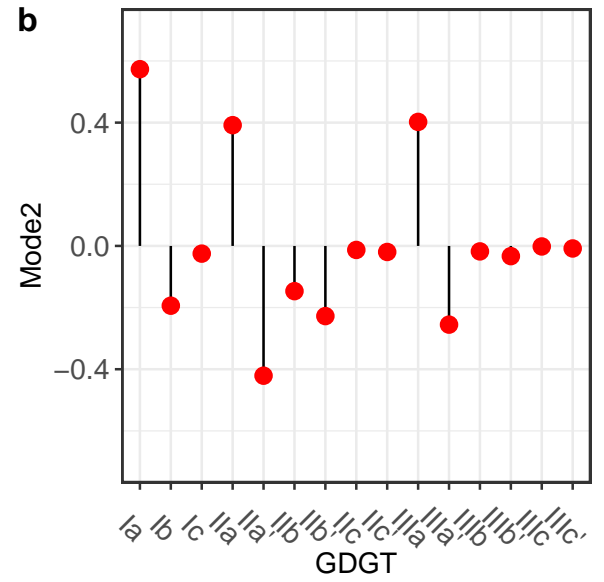

Figure 3: Loadings calculated through EOF analysis for of each brGDGT for a) Mode 1, and b) Mode 2 . 

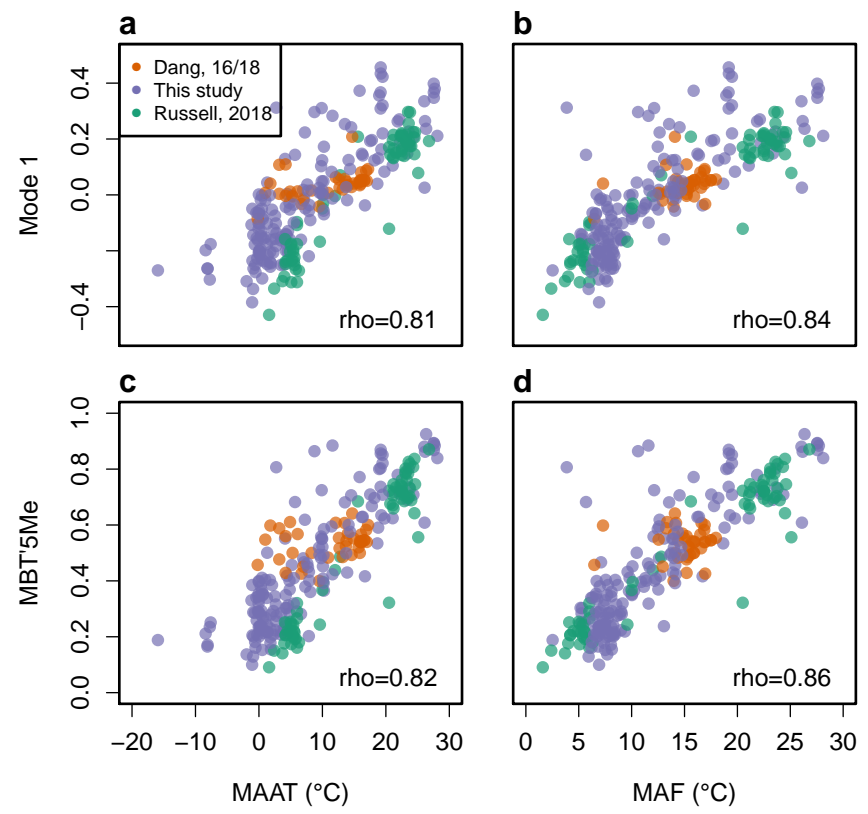

Figure 4: Scatter plots of MAAT (a and c), and MAF (b and d) against values for Mode 1 (a and b) and $M B T_{5 M e}^{\prime}$ (c and d). Correlation values are presented for each plot. Samples are color coded following Figure 1 . 

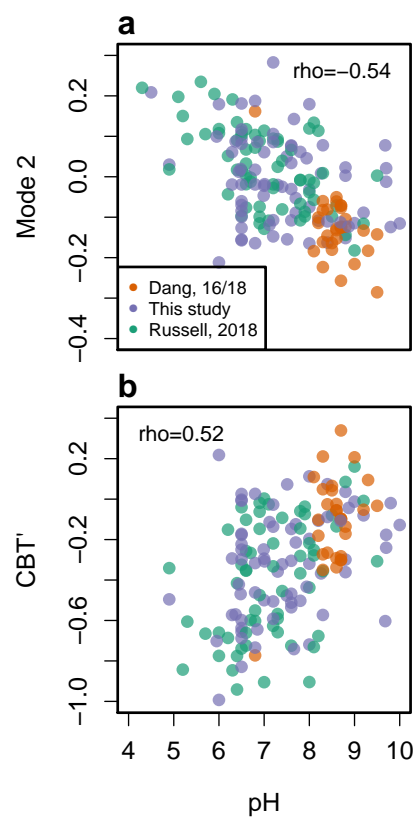

Figure 5: Scatter plots of $\mathrm{pH}$ against values for a) Mode 2, and b) $C B T^{\prime}$. Correlation values are presented for each plot. Samples are color coded following Figure 1 


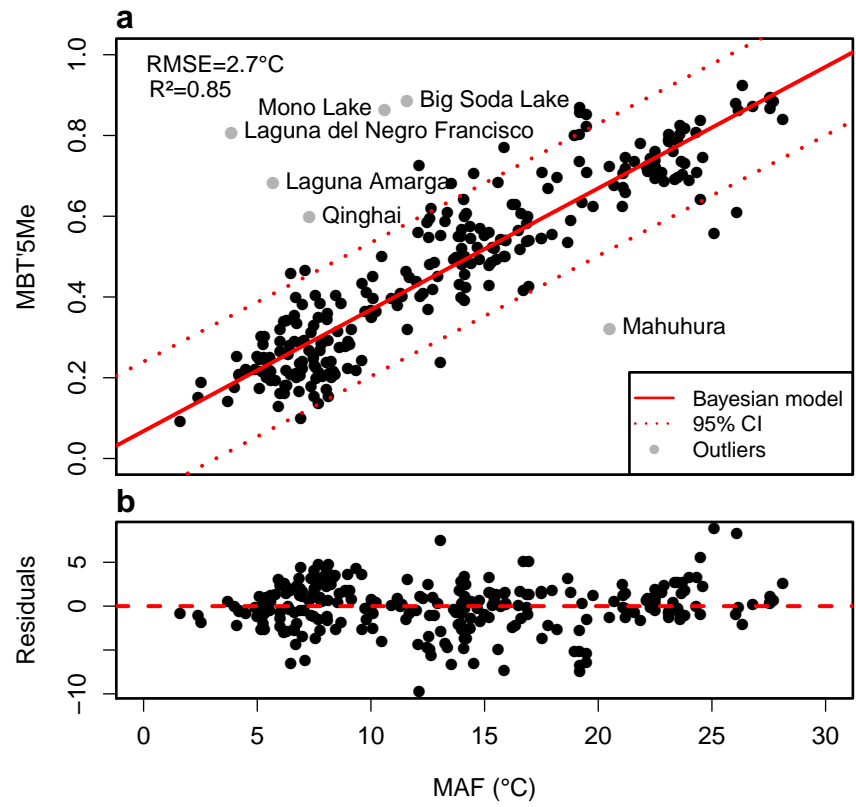

Figure 6: Bayesian regression calculated for $M B T_{5 M e}^{\prime}$ as a function of MAF. a) Scatter plot showing the regression with fitted line (solid red) and the $95 \%$ Confidence Interval (dotted red) for the dataset without outliers (labeled and shown in grey). Calculated $R^{2}$ and RMSE values for the regression are indicated in the corner. b) Residuals plotted against MAF. 

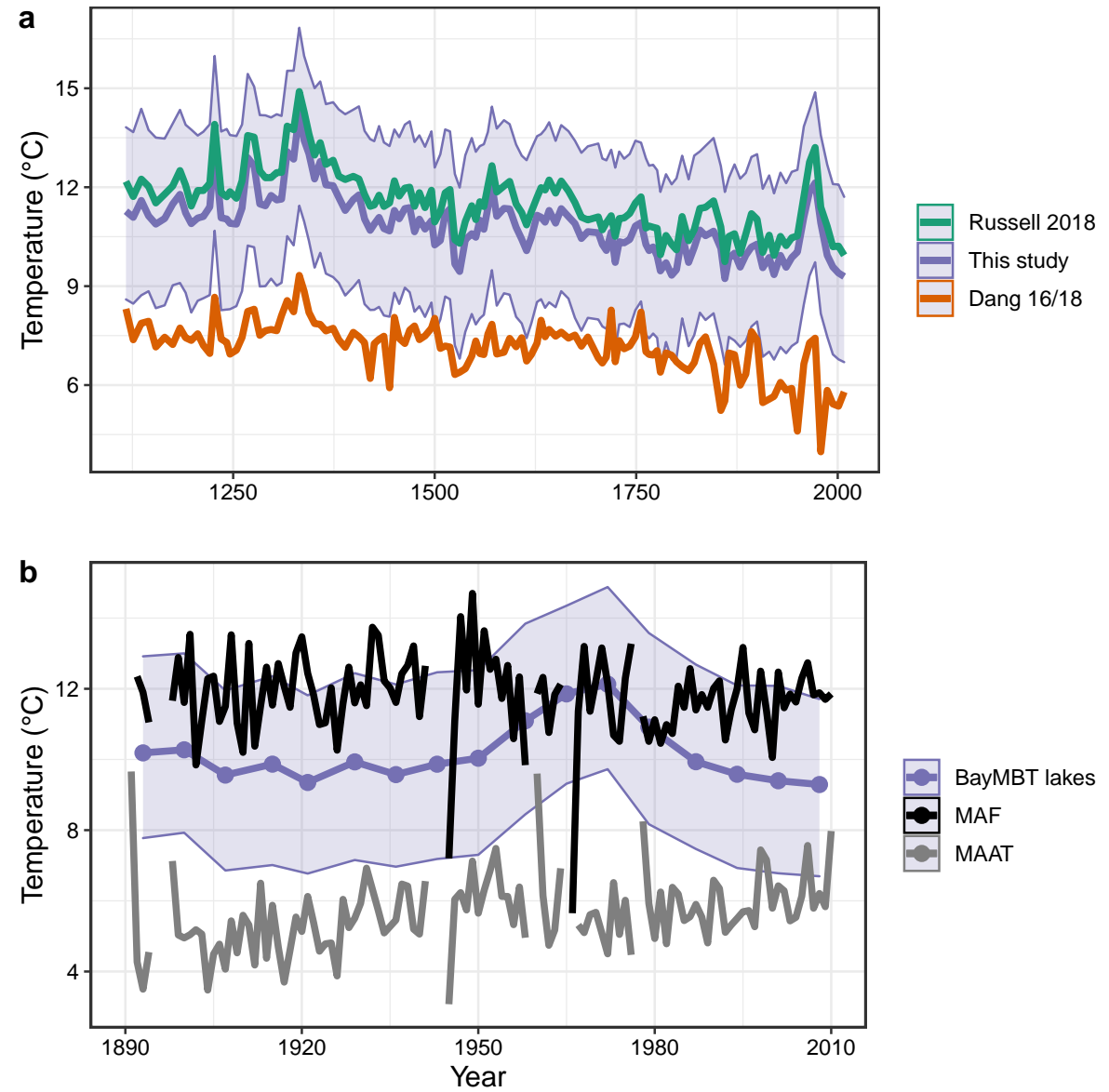

Figure 7: Temperature reconstruction for the Basin Pond record (Miller et al. 2018). a) Reconstructions using the Russell et al. (2018), Dang et al. (2018), and the Bayesian calibration from this work are shown in green, orange and purple, respectively. Purple shaded area indicate the $1 \sigma$ error range for the Bayesian results. b) BayMBT median results (purple) with the $1 \sigma$ bounds (shaded purple area) compared with the instrumental record (1891-2019) from Farmington, ME. Record for MAAT is shown as a gray line, MAF shown as a black line. 


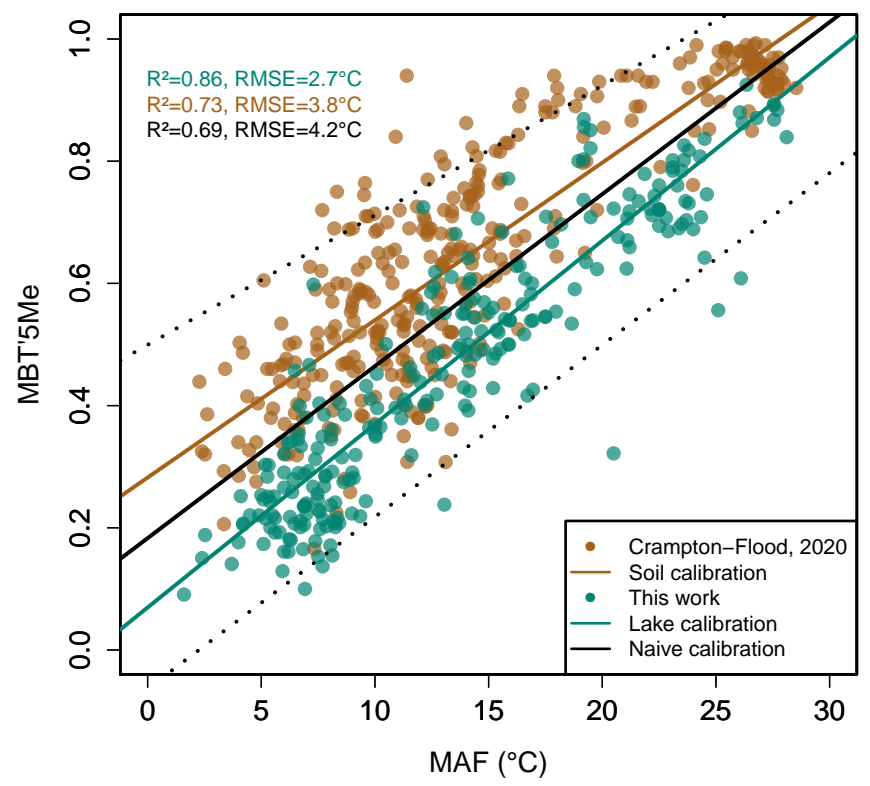

Figure 8: Scatter plot of $M B T_{5 M e}^{\prime}$ as a function of MAF for soils and peats (brown, Dearing Crampton-Flood et al. (2020) ) and lakes (green, this study). Bayesian calibration curves, $R^{2}$, and RMSE values for soils (brown), lakes (green), and for the combined dataset (black) with the $95 \%$ CI (dotted black). 


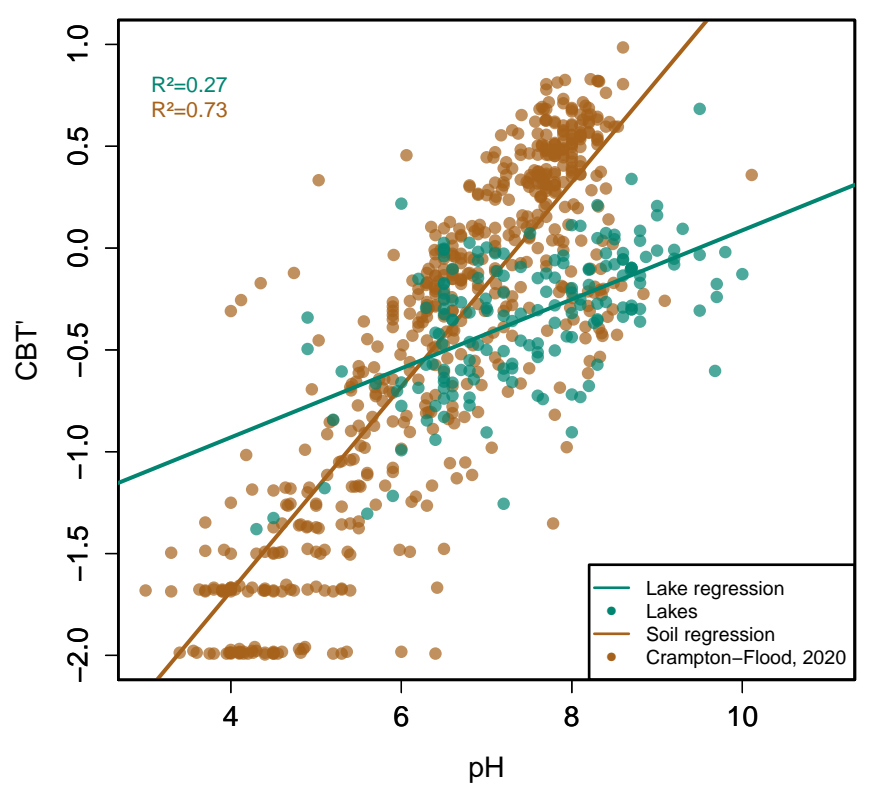

Figure 9: Scatter plot and linear regressions of $C B T^{\prime}$ as a function of $\mathrm{pH}$ for soil and peat samples (brown, Dearing Crampton-Flood et al. (2020) ) and lakes (green, this study). $R^{2}$ values for each regression shown on top left. 

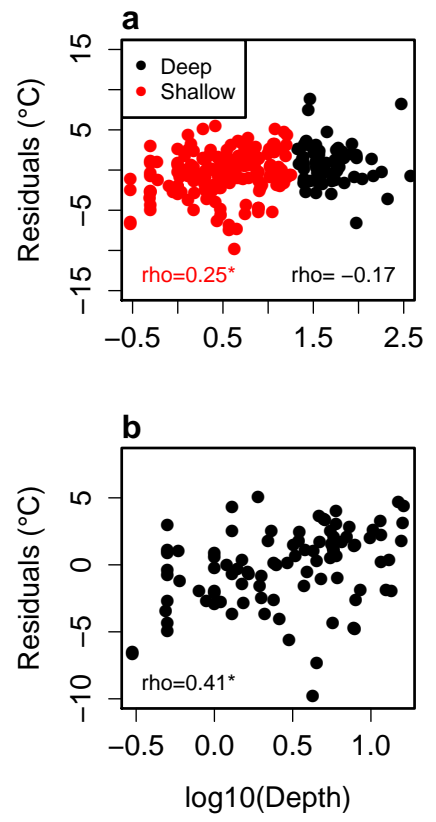

Figure 10: Scatter plots and correlations of the calibration residuals as a function of the $\log _{10}$ of depth. a) Lakes are separated into shallow (red, $<20 \mathrm{~m}$ ) and deep (black, $>20 \mathrm{~m}$ ) groups. The Spearman correlation for each subset is shown; asterisks mark significant correlations $(p<0.05)$. b) Shallow lakes from temperate latitudes $\left(>35^{\circ} \mathrm{N}\right.$ and $\left.\mathrm{S}\right)$. Spearman correlation is shown. 


\begin{tabular}{|l|c|}
\hline Parameters & Correlation \\
\hline MAF - pH & $0.38^{*}$ \\
MAF - MAP & $-0.27^{*}$ \\
MAF - Depth & 0.07 \\
MAF - Conductivity & $0.55^{*}$ \\
\hline pH - MAP & $-0.40^{*}$ \\
pH - Depth & -0.09 \\
pH - Conductivity & $0.62^{*}$ \\
\hline MAP - Depth & 0.05 \\
MAP - Conductivity & $-0.78^{*}$ \\
\hline Conductivity - Depth & 0.06 \\
\hline
\end{tabular}

Table 1: Spearman correlation values for each pair of environmental parameters considered in our dataset. Statistically significant correlations $(\rho<0.05)$ are marked with an *.

\begin{tabular}{|c|c|c|}
\hline Parameter & Mode 1 & Mode 2 \\
\hline MAF & $0.84^{*}$ & $-0.31^{*}$ \\
MAAT & $0.81^{*}$ & $-0.18^{*}$ \\
pH & $0.32^{*}$ & $-0.54^{*}$ \\
MAP & -0.01 & $0.53^{*}$ \\
Conductivity & $0.47^{*}$ & $-0.79^{*}$ \\
Depth & $-0.14^{*}$ & 0.01 \\
\hline
\end{tabular}

Table 2: Spearman correlation values for both Modes and all studied environmental parameters. Statistically significant correlations $(\rho<0.05)$ are marked with an *. 


\begin{tabular}{|c|c|c|c|c|c|c|}
\hline Index & MAF & MAAT & $\mathrm{pH}$ & MAP & Conductivity & Depth \\
\hline$M B T_{5 M e}^{\prime}$ & $0.86^{*}$ & $0.82^{*}$ & $0.35^{*}$ & -0.04 & 0.55 & -0.08 \\
$M B T_{6 M e}^{\prime}$ & $0.40^{*}$ & $0.52^{*}$ & -0.14 & $0.39^{*}$ & $-0.32^{*}$ & -0.11 \\
$C B T^{\prime}$ & $0.36^{*}$ & $0.22^{*}$ & $0.52^{*}$ & $-0.55^{*}$ & $0.81^{*}$ & 0.03 \\
$I R$ & $0.64^{*}$ & $0.52^{*}$ & $0.49^{*}$ & $-0.42^{*}$ & $0.76^{*}$ & 0.04 \\
$f C$ & $0.64^{*}$ & $0.60^{*}$ & $0.48^{*}$ & $-0.22^{*}$ & $0.56^{*}$ & -0.12 \\
\hline
\end{tabular}

Table 3: Spearman correlation values for calculated indices and environmental parameters. Statistically significant correlations $(\rho<0.05)$ are marked with an *. 